\title{
Method to generate growth and degrowth models obtained from differential equations applied to agrarian sciences
}

\section{Método gerador de modelos de crescimento e decrescimento obtidos a partir de equações diferenciais aplicado as ciências agrárias}

\author{
André Luiz Pinto dos Santos ${ }^{1 *}$; Guilherme Rocha Moreira ${ }^{2}$; Cicero Carlos Ramos \\ de Brito $^{3}$; Frank Gomes-Silva ${ }^{2}$; Maria Lindomárcia Leonardo da Costa ${ }^{4}$; \\ Patrícia Guimarães Pimentel'; ${ }^{5}$ Moacyr Cunha Filho ${ }^{2}$; Ivone Yurika Mizubuti ${ }^{6}$
}

\begin{abstract}
This study aims to propose a method to generate growth and degrowth models using differential equations as well as to present a model based on the method proposed, compare it with the classic nonlinear mathematical models Logistic, Von Bertalanffy, Brody, Gompertz, and Richards, and identify the one that best represents the mean growth curve. To that end, data on Undefined Breed (UB) goats and Santa Inês sheep from the works of Cavalcante et al. (2013) and Sarmento et al. (2006a), respectively, were used. Goodness-of-fit was measured using residual mean squares (RMS), Akaike information criterion (AIC), Bayesian information criterion (BIC), mean absolute deviation (MAD), and adjusted coefficient of determination $\left(R_{a}^{2}\right)$. The models' parameters ( $\alpha$, weight at adulthood; $\beta$, an integration constant; $\gamma$, shape parameter with no biological interpretation; $k$, maturation rate; and $m$, inflection point) were estimated by the least squares method using Levenberg-Marquardt algorithm on the software IBM SPSS Statistics 1.0. It was observed that the proposed model was superior to the others to study the growth curves of goats and sheep according to the methodology and conditions under which the present study was carried out.
\end{abstract}

Key words: Growth curve. Non-linear model. New model. Model selection.

\section{Resumo}

O objetivo deste trabalho é propor um método gerador de modelos de crescimento e decrescimento por meio de equações diferenciais, bem como apresentar um modelo a partir do método proposto, compará-lo entre os modelos matemáticos não lineares clássicos seguintes, Logístico, Von Bertalanffy, Brody, Gompertz, e Richards e identificar aquele que representa melhor a curva média de crescimento. Para isso, foram utilizados dados de caprino (SRD - Sem Raça Definida) e de ovinos da raça Santa Inês oriundos, respectivamente, dos trabalhos de Cavalcante et al. (2013) e Sarmento et al. (2006a). A qualidade de ajuste foi medida por meio do quadrado médio do resíduo $(Q M R)$, critério de informação

\footnotetext{
1 Discente, Curso de Doutorado, Programa de Pós-Graduação em Biometria e Estatística Aplicada, Universidade Federal Rural de Pernambuco, UFRPE, Recife, PE, Brasil. E-mail: andredefensor@hotmail.com

2 Profs., Programa de Pós-Graduação em Biometria e Estatística Aplicada, UFRPE, Recife, PE, Brasil. E-mail: guirocham@gmail. com; franksinatrags@gmail.com; moacyr.cunhafo@ufrpe.br

3 Prof., Instituto Federal de Pernambuco, IFPE, Recife, Brasil. E-mail: cicerocarlosbrito@yahoo.com.br

4 Prof ${ }^{\text {a }}$ Departamento de Zootecnia, Universidade Federal da Paraíba, UFPB, Areia, PB, Brasil. E-mail: lindomarciacosta@gmail.com

5 Prof ${ }^{\mathrm{a}} \mathrm{Dr}^{\mathrm{a}}$, Departamento de Zootecnia, Universidade Federal do Ceará, UFCE, Ceará, CE, Brasil. E-mail: pgpimentel@hotmail.com

${ }^{6}$ Prof $^{\mathrm{a}} \mathrm{Dr}^{\mathrm{a}}$, Departamento de Zootecnia, Universidade Estadual de Londrina, UEL, Londrina, PR, Brasil. E-mail: mizubuti@uel.br

* Author for correspondence
} 
de Akaike (AIC), critério de informação Bayesiano (BIC), desvio médio absoluto (DMA) e coeficiente de determinação ajustado $\left(R_{a}^{2}\right)$. Os parâmetros dos modelos ( $\alpha$, peso à idade adulta; $\beta$, uma constante de integração; $\gamma$, parâmetro de forma sem interpretação biológica; $k$, taxa de maturação; e $m$, ponto de inflexão) foram estimados pelo método de mínimos quadrados utilizando o algoritmo de LevenbergMarquardt por meio do Software IBM SPSS Statistics 1.0. Observou-se que o modelo Proposto foi superior aos outros modelos para o estudo das curvas de crescimento de caprinos e ovinos de acordo com a metodologia e condições em que foi desenvolvido o presente estudo.

Palavras-chave: Curva de crescimento. Modelo não linear. Novo modelo. Seleção de modelo.

\section{Introduction}

The Northeast region of Brazil is a major player in goat and sheep husbandry since it hosts over half of the country's domestic herd of those animals (PRODUÇÃO PECUÁRIA MUNICIPAL, 2012), whose main food source for livestock production is native pastures (caatinga). One of the most important goals in goat and sheep husbandry is to obtain adequate weight within a short timeframe.

In a genetic improvement program for goats or sheep, the growth curve study may be used to describe animal development over time, which helps establish strategies in feeding programs and describe the optimal slaughter age (CARNEIRO et al., 2007; MALHADO et al., 2008a; SANTANA et al., 2001).

According to Teixeira et al. (2012), animal growth curves are studied by fitting non-linear models since that enables synthesizing precise information on weight gain and prognostics for animals of the same breed under the same environmental conditions.

The literature present studies comparing nonlinear models for fitting growth curves of goats and sheep. According to Malhado et al. (2009) and Chalh and El Gazzah (2014), the five most traditionally used models used to describe animal growth are the Logistic (NELDER, 1961), Von Bertalanffy (VON BERTALANFFY, 1957), Gompertz (LAIRD, 1965), Brody (BRODY, 1945), and Richards (RICHARDS, 1959). Thus, a large volume of information can be taken into account in three or four parameters that may be interpreted biologically, such as asymptotic weight $(\alpha)$ and growth rate $(k)$ (McMANUS et al., 2010).
Some researchers have studied those models in goats (SOUSA et al., 2011; DO Ó et al., 2012) and in sheep (SOUZA et al., 2011; TEIXEIRA NETO et al., 2016), which requires some criteria to select the most competitive ones (GUEDES et al., 2005; SARMENTO et al., 2006b).

Given the dynamics of mathematical model application in biological researches, some authors such as Brito et al. (2007), Lima Filho (2012), and Santana et al. (2016) understand more studies on animal growth curves are still needed and that there is room for new models that may lead to more significant results and more precise estimates. Therefore, it is always possible a new model will have better performance in terms of biological interpretations and convergence of parameters (SANTANA et al., 2016).

Thus, this study aims to present a method to generate growth and degrowth models using differential equations, as well as to propose a model based on such method and compare it with the commonly used non-linear mathematical models to identify the one that indicates the best goodness-offit to the growth curves of Undefined Breed (UB) goats and Santa Inês sheep.

\section{Material and Methods}

Data

This study will use two goat and sheep growth databases originally presented in the papers by Cavalcante et al. (2013) and Sarmento et al. (2006a), respectively. 
Cavalcante et al. (2013) applied the non-linear Logistic models and Von Bertalanffy to weight data of 23 UB goats reared in the Santiago community in the municipality of Simplício Mendes, PI, Brazil, from birth to 185 days of age, obtained between May and November 2009 for a total of 575 data points.

Sarmento et al. (2006a) used weight records from birth to 196 days of age of 927 Santa Inês lambs, controlled from 1983 to 2000, belonging to the Empresa Estadual de Pesquisa Agropecuária da Paraiba (EMEPA-PB), located in the municipality of Soledade, PB, Brazil.

Method to generate growth and degrowth models obtained from differential equations

According to Von Bertalanffy (1957), the variation in animal growth as a function of time is proportional to the difference between the synthesis (anabolism) and breakdown (catabolism) of the body building material, which was expressed in mathematical terms as

$$
\frac{d W(t)}{d t}=\eta W^{m}(t)-k W^{n}(t)
$$

where $W(t)$ represents body weight, $t$ represents time, $m$ and $n$ are constants, and $\eta$ and $k$ represent the anabolism and catabolism constants, respectively. Expression (1) corresponds to the allometry law, which states the synthesis and breakdown process rate in a body may be expressed as a power function.

Inspired on the biological hypothesis by Von Bertalanffy (1957), given by (1), we propose a method of initially quite broad character, presented below. The sum of the variations in growths and/or degrowths in relation to variables $\boldsymbol{x}=\left(x_{1}, x_{2}, \ldots, x_{k}\right)$ is proportional to anabolism and catabolism, i.e.,

$$
\begin{aligned}
& \sum_{l_{1}=0, \ldots, l_{k}=0}^{n_{1}, \ldots, n_{k}} a_{l_{1}, \ldots, l_{k}} f_{l_{1}, \ldots, l_{k}}(\boldsymbol{x}) \frac{\partial^{l_{1}+\cdots+l_{k}} W(\boldsymbol{x})}{\partial x_{1}^{l_{1}} \ldots \partial x_{k}^{l_{k}}} \\
= & a W^{\theta}(\boldsymbol{x}) f(\boldsymbol{x})-b W^{\lambda}(\boldsymbol{x}) \mathrm{g}(\boldsymbol{x}),
\end{aligned}
$$

$$
\text { where } f(\boldsymbol{x}) \geq 0, g(\boldsymbol{x}) \geq 0, f_{l_{1}, \ldots, l_{k}}(\boldsymbol{x}) \geq 0,
$$

$$
\sum_{i=1}^{k} l_{i} \geq 1, a \geq 0, b \geq 0, a+b>0,
$$

$\theta \in \mathfrak{R}$, and $\lambda \in \mathfrak{R}$. It can be seen that Equation (2) may contemplate not only the time variable, but also other important variables for the comprehension of growth. Despite this possibility, we present below a sub-case of (2) in an attempt to generalize, as much as possible, the idea contained in (1). Indeed, under conditions $k=1, n_{1}=1, a_{0}=0, a_{1}=1, f_{0}\left(x_{1}\right)=$ $0, f_{1}\left(x_{1}\right)=1$, and $x_{1}=t$, we can describe Equation (2) in a more simplified way:

$$
\frac{d W(t)}{d t}=a W^{\theta}(t) f(t)-b W^{\lambda}(t) g(t) .
$$

Although (3) is a particular case of Equation (2), it admits as sub-cases all non-linear growth (and degrowth) models well established in the literature, obtained through differential equations, as seen in Table 1. At the same time (3) generalizes pre-existing models, this equation is adequate to generate new model proposals. Considering, in (3), $\theta=1, \lambda=0, f(t)=\mathrm{e}^{\mathrm{kt}}$, and $g(t)=a \mathrm{e}^{\mathrm{kt}}$, we have the following expression:

$$
\frac{d W(t)}{d t}=a W(t) \mathrm{e}^{\mathrm{kt}}-a b \mathrm{e}^{\mathrm{kt}}
$$


Table 1. Growth/degrowth models generated from Equation (3).

\begin{tabular}{|c|c|c|c|c|c|c|c|}
\hline Models & $a$ & $b$ & $\theta$ & $\lambda$ & $f(t)$ & $g(t)$ & Model generated \\
\hline Logistic (NELDER, 1961) & - & - & 2 & 1 & 1 & 1 & $W(t)=\frac{\alpha}{1+\beta \mathrm{e}^{-\mathrm{kt}}}+\varepsilon$ \\
\hline Von Bertalanffy (VON BERTALANFFY, 1957) & - & - & $2 / 3$ & 1 & 1 & 1 & $W(t)=\alpha\left(1-\beta \mathrm{e}^{-\mathrm{kt}}\right)^{3}+\varepsilon$ \\
\hline Brody (BRODY, 1945) & - & - & 0 & 1 & 1 & 1 & $W(t)=\alpha\left(1-\beta \mathrm{e}^{-\mathrm{kt}}\right)+\varepsilon$ \\
\hline Gompertz (LAIRD, 1965) & - & - & 1 & 1 & 1 & 1 & $W(t)=\alpha \mathrm{e}^{-\beta \mathrm{e}^{(-k t)}}+\varepsilon$ \\
\hline Chapm-Richard (RICHARDS, 1959) & - & - & - & 1 & 1 & 1 & $W(t)=\alpha\left(1-\beta \mathrm{e}^{-k t}\right)^{m}+\varepsilon$ \\
\hline Mitscherlich (DA SILVA, 1986) & - & - & 0 & 1 & 1 & 1 & $W(t)=\alpha\left(1-k^{t}\right)+\varepsilon$ \\
\hline Brito-Silva 2 (BRITO et al., 2007) & - & - & 1 & 1 & $\mathrm{e}^{\eta t}$ & $\mathrm{e}^{\eta t}$ & $W(t)=\alpha\left(\mathrm{e}^{\beta \mathrm{e}^{\mathrm{kt}}+\gamma \mathrm{e}^{\rho t}}\right)+\varepsilon$ \\
\hline Silva-Bailey (DA SILVA, 1986) & - & 0 & 1 & - & $\eta^{t}$ & - & $W(t)=\alpha \mathrm{e}^{\mathrm{k} \gamma^{t}}+\varepsilon$ \\
\hline Exponential decay & 0 & - & - & 1 & - & $t$ & $W(t)=\alpha \mathrm{e}^{-k \mathrm{t}}+\varepsilon$ \\
\hline Exponential growth & - & 0 & 1 & - & $t$ & - & $W(t)=\alpha \mathrm{e}^{k t}+\varepsilon$ \\
\hline Weibull & - & - & 0 & 1 & $t^{\gamma}$ & $t^{\gamma}$ & $W(t)=\alpha-\beta \mathrm{e}^{\mathrm{k}^{t}}+\varepsilon$ \\
\hline Proposed & - & - & 1 & 0 & $\mathrm{e}^{k t}$ & $a \mathrm{e}^{k t}$ & $W(t)=\alpha\left(1+\beta \mathrm{e}^{\gamma \mathrm{e}^{\mathrm{kt}}}\right)+\varepsilon$ \\
\hline
\end{tabular}

It is important to note that, since $b$ is constant, Equation (4) can be written as

$$
\frac{d W(t)}{d t}-\frac{d b}{d t}=a \mathrm{e}^{\mathrm{kt}}(W(t)-b)
$$

and, after some algebra development, we arrive at the following expression:

$$
W(t)=b\left[1+\frac{\mathrm{e}^{c}}{b} \mathrm{e}^{\frac{a}{k}\left(\mathrm{e}^{k t}\right)}\right] .
$$

Equation (4) constitutes our proposed model, whose solution in a more operational manner is found on the last row of Table 1 by plugging $b=\alpha$, $\frac{\mathrm{e}^{c}}{b}=\beta$ and $\frac{a}{k}=\gamma$ into Equation (5).

In order to test and compare the models, we used the Logistic, Von Bertalanffy, Brody, Gompertz, Richards, and Proposed models (Table 1).

In these models, $W(t)$ is body weight $(\mathrm{kg})$ at age $t ; t$ is time, $k$ is the specific maturation rate, which indicates the rate at which the animal approaches its size in adulthood (SARMENTO et al., 2006b); $\alpha$ is the asymptotic weight when $t$ tends to infinite (this parameter is interpreted as weight in adulthood); $m$ is the parameter that shapes the curve; $\beta, \varphi$, and $\gamma$ are shape parameter with no biological interpretation; $\mathrm{e}$ is the exponential; and $\varepsilon$ is the random error associated with each weighing following normal distribution with average zero and constant variance. The estimates of the model parameters for goat and sheep data were obtained through the least squares method using the Levenberg-Marquardt iterative process in the software IBM SPSS Statistics 1.0 [2017?].

\section{Criterion for model selection}

The criteria employed to select the model that best describes the growth curve were: 
a. The residual mean squares (RMS) is calculated by dividing the sum of the residual squares by the degrees of freedom of the residue $n-p$, i.e.,

$$
R M S=\sum_{i=1}^{n} \frac{\left(y_{i}-y_{i}\right)^{2}}{n-p},
$$

b. Akaike information criterion (AKAIKE, 1974) - AIC and Bayesian information criterion - BIC (SCHWARZ, 1978), defined as:

$$
\begin{aligned}
& A I C=n+n \log (2 \pi)+n \log \left(\frac{S Q_{\text {res }}}{n}\right)+2(p+1), \text { and } \\
& B I C=n+n \log (2 \pi)+n \log \left(\frac{S Q_{\text {res }}}{n}\right)+(\log n)(p+1) .
\end{aligned}
$$

According to Sousa et al. (2010), the AIC and BIC criteria imposes a penalty according to the number of parameters to be estimated.

c. The mean absolute deviation of the residues MAD, as suggested by Sarmento et al. (2006b), obtained by the following formula:

$$
M A D=\frac{\sum_{i=1}^{n}\left|y_{i}-\hat{y}_{i}\right|}{n},
$$

d. Adjusted coefficient of determination: Since the coefficient of determination $R^{2}$ increases as a new variable is added to the mathematical model, one alternative to correct this issue when comparing functions with different numbers of parameters is to use as criterion the adjusted coefficient of determination, calculated as follows:

$$
R_{a}^{2}=R^{2}-\frac{p-1}{n-p}\left(1-R^{2}\right)
$$

For the previous items: $S Q_{\text {res }}$ is the sum of squares of the residues, defined by $S Q_{\text {res }}=\sum_{i=1}^{n}\left(\hat{y}_{i}-y_{i}\right)^{2}$ $; y_{i}$ is the observed weight; $\hat{y}_{i}$ is the estimated weight (prediction) of $y_{i} ; n$ is the number of observations; $p$ is the number of free parameters in the model; and $\bar{y}$ is the average of the observations. Thus, the best adjusted model is the one that has the lowest values for RMS, AIC, BIC, and MAD and the highest $R_{a}^{2}$ value.

\section{Clustering analysis and absolute growth rate}

In the next step, those data underwent clustering analysis in the free software $\mathrm{R}$ version 3.4.0. In order to verify the fit between the dissimilarity matrix and the dendrograms obtained from each clustering method, the cophenetic correlation coefficient that more consistently indicated the average linkage method was calculated based on the mean Euclidian distance. Next, the adjusted Rand index (HUBERT; ARABIE, 1985) was used to determine the number of clusters aiming to group the models so that there is heterogeneity among and homogenicity within the clusters according to the value of the indicators. After the best model was chosen, we calculated the absolute growth rate (AGR), obtained from the first derivate of the adjusted model in relation to time $(\partial W(t) / \partial t)$.

\section{Results and Discussion}

\section{Goat data}

The estimates of parameters $\alpha, \beta, k, \gamma$, and $m$ in the adjusted models and the values of RMS, $\mathrm{AIC}, \mathrm{BIC}, \mathrm{MAD}, k$, and $R_{a}^{2}$, used to evaluate which model best described the mean growth curve of UB goats are presented in Table 2. 
Table 2. Estimated values of parameters $\alpha, \beta, k, \gamma$, and $m$ along with the goodness-of-fit statistics RMS, AIC, BIC, MAD, and $R_{a}^{2}$ for the Logistic, Von Bertalanffy, Brody, Gompertz, Richards, and Proposed models adjusted to data on UB goats.

\begin{tabular}{|c|c|c|c|c|c|c|c|c|c|c|}
\hline \multirow{2}{*}{ Models } & \multicolumn{5}{|c|}{ Parameters } & \multicolumn{5}{|c|}{ Indicators } \\
\hline & $\hat{\alpha}$ & $\hat{\beta}$ & $\hat{k}$ & $\hat{\gamma}$ & $\hat{m}$ & RMS & $\mathrm{AIC}$ & $\mathrm{BIC}$ & MAD & $R_{a}^{2}$ \\
\hline Logistic & 19.84 & 6.35 & 0.020 & & & 0.09 & 16.62 & 21.49 & 0.25 & 0.996 \\
\hline Von Bertalanffy & 30.44 & 0.58 & 0.007 & & & 0.11 & 20.59 & 25.47 & 0.49 & 0.995 \\
\hline Brody & 759.43 & 0.99 & 0.000 & & & 0.14 & 27.31 & 32.20 & 7.17 & 0.994 \\
\hline Gompertz & 25.21 & 2.35 & 0.010 & & & 0.10 & 18.35 & 23.23 & 0.25 & 0.995 \\
\hline Richards & 25.69 & 0.10 & 0.009 & & 23.20 & 0.11 & 20.59 & 26.69 & 0.44 & 0.995 \\
\hline Proposed & 18.27 & -1.17 & 0.012 & -0.30 & & 0.08 & 14.94 & 21.03 & 0.24 & 0.996 \\
\hline
\end{tabular}

The estimates of $\hat{\alpha}$, for the models at hand, proved similar to the analyses of genetic aspects of the growth curve of Anglo-Nubian goats (SOUSA et al., 2011), however, we found lower values of those estimates in other studies (CARNEIRO et al., 2009; MALHADO et al., 2008a). One exception was the Brody model, which overestimated weight from birth to adulthood (759.43 kg). Pires et al. (2017), while studying the growth curve of Repartida goats reared in the caatinga, reported the overestimation of this parameter both for the Richards function and the Brody function.

One justification for the estimate of parameter $\alpha$, which indicates adult weight may be because the data on UB goats used came from animals no more than six months of age (CAVALCANTE et al., 2013). According to Brown et al. (1976), this is not the maximum weight the animal reaches, but rather the mean weight at maturity, free of seasonal variations. Moreover, studies state there are conflicting opinions on the optimal adult weight of an animal, which will depend on the species, breed, previous selection, management system adopted, and climate conditions (CARNEIRO et al., 2009).

When analyzing parameter $k$, an important indicator of precocity, it was found that the Gompertz, Proposed, and Logistic models had the highest values $(0.010,0.012$, and 0.020$)$ and that the Von Bertalanff and Richards models had the lowest values (0.007 and 0.009), whereas the Brody function overestimated this parameter. The models that found the most precocity of $k$, indicated the lowest adult weights $\alpha$, i.e., as maturity rate drops, asymptotic weight increases. This inverse behavior has been reported by other researchers (McMANUS et al., 2003; SARMENTO et al., 2006b; MALHADO et al., 2009).

Parameter $\beta$ is related to the intercept, i.e., an integration constant related to the initial animal weights and with no well-defined biological interpretation. $m$ is the inflection point of the curve and indicates the moment the animal switches from a rapid growth phase to a slow growth phase. Finally, parameter $\gamma$, which appears in the Proposed model, is used to increase the model's flexibility in data fitting.

In the literature, few papers were found with references to studies on UB goat growth curve (OLIVEIRA et al., 2009). However, great variation was found in the choice of models that best fit the growth curve of goats.

For data on Mambrina and Anglo-Nubian goats reared in the caatinga, Carneiro et al. (2009), Malhado et al. (2008a), and Sousa et al. (2011) found the best fits using the Logistic, Bertalanffy, and Brody models, respectively. According to 
Sarmento et al. (2006b), this difference concerning the adjusted models is subjectively understandable since it will depend on the growth pattern of the animals studied.

However, in the present study, the best fit was found for the proposed model, which had the lowest values for the statistics RMS, AIC, BIC, and MAD and the highest $R_{a}^{2}$ value, followed by the Logistic, Gompertz, Richards, Von Bertalanffy, and Brody models, as seen in Table 2 .

This result was corroborated by the clustering analysis based on the criteria employed, which showed the formation of five clusters (Figure 1), the first formed by the Brody model, the second, by the Von Bertalanffy and Richards models, the third, by the Gompertz model, the fourth, by the Logistic model, and the last, by the Proposed model. The plot with the growth curve adjusted by the Proposed model is presented in Figure 2. A visual analysis shows that this model provided good fit.
The AGRs obtained by the first derivate of the Proposed model over time showed growth up to the maximum around $0.100 \mathrm{~kg}$ /day and degrowth with age. The curve's inflection point occurred at 83 days of age, at weight of approximately $6.72 \mathrm{~kg}$ (Figure $3)$.

Previous studies on Anglo-Nubian goats showed an inflection point at 71 days and AGR of 0.130 $\mathrm{kg}$ /day (MALHADO et al., 2008a). For males and females, respectively, these measures were 100 and 83 days of age and 0.146 and $0.127 \mathrm{~kg}$ /day for Mambrina goats of the same region in the state of Bahia (CARNEIRO et al., 2009).

According to Souza et al. (2013), the inflection point is important to aid producers in specific feeding programs and in defining the best slaughter age for the best cost/benefit ratio. According to Teixeira Neto et al. (2016), the inflection point and the AGR may be influenced by environmental and/ or genetic factors.

Figure 1. Dendrogram obtained by the clustering method based on the quality indicators (RMS, AIC, BIC, MAD, and $R_{a}^{2}$ ) for the Logistic, Von Bertalanffy, Brody, Gompertz, Richards, and Proposed models.

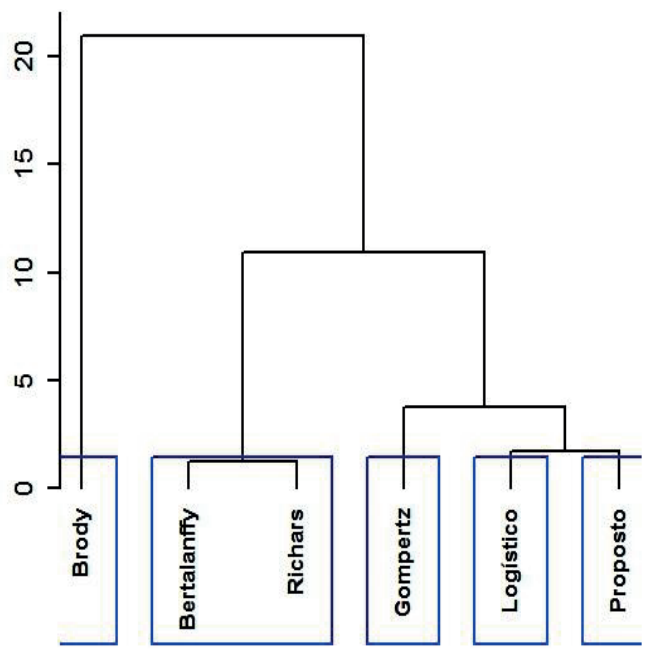


Figure 2. Weight as a function of age according to the Proposed model observed in UB goats.

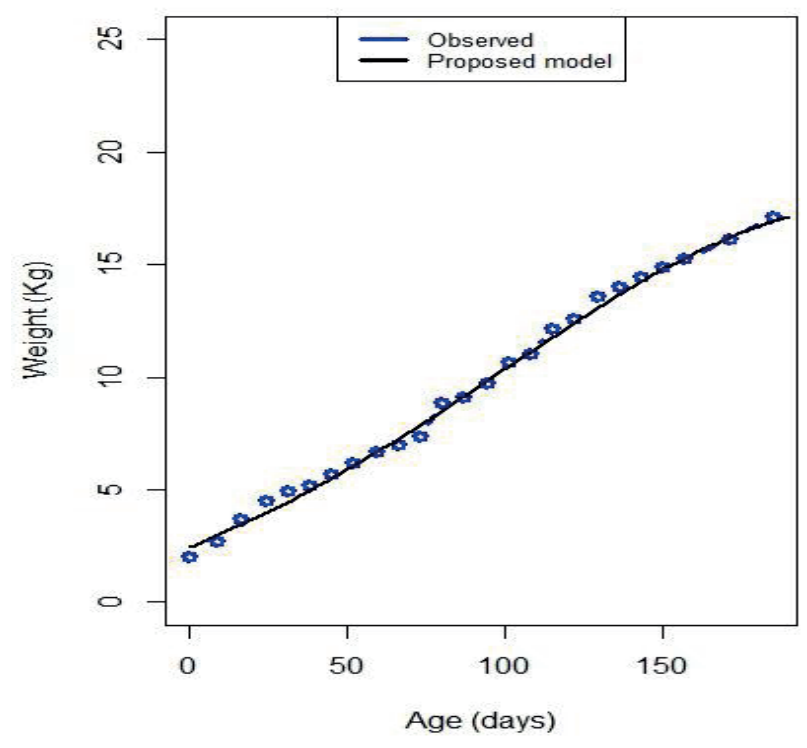

Figure 3. AGR estimated by the Proposed model.

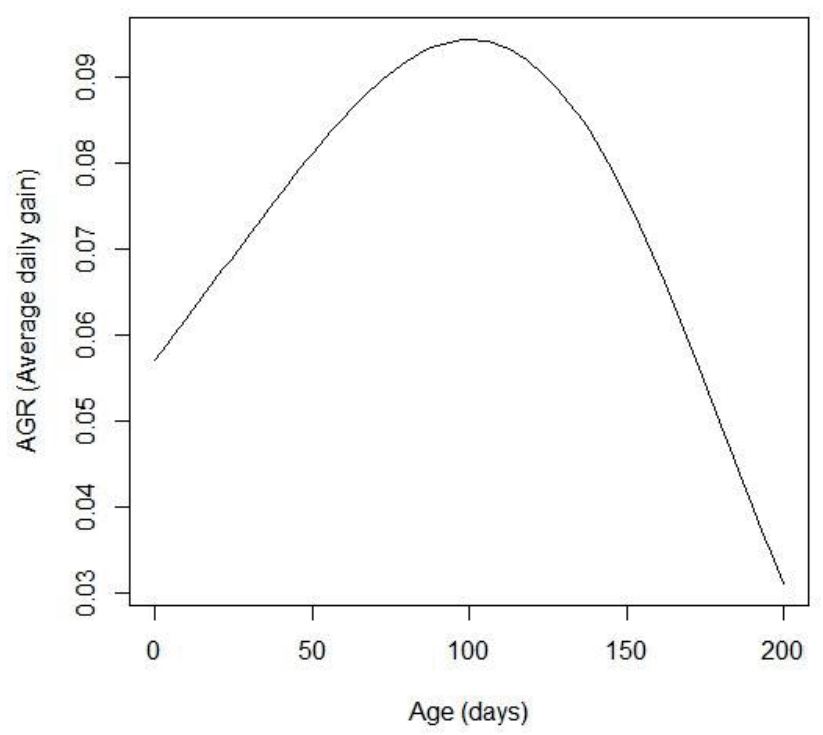

The estimated correlation between parameters $\alpha$ and $k$ was significant and equal to -0.89 for the proposed model and match studies on AngloNubian (MALHADO et al., 2008a) and Mambrina (CARNEIRO et al., 2009) goats. The most important biological ratio for a curve is between parameters $\alpha$ and $k$ (McMANUS et al., 2003). The negative correlation between these two parameters indicates animals with lower growth rates reach greater weights at maturity.

\section{Sheep data}

Table 3 presents the estimates of the parameters for each model and the criteria employed to assess the model that best described the mean growth curve of Santa Inês sheep. 
Table 3. Estimated values of $\hat{\alpha}, \hat{\beta}, \hat{k}, \hat{\gamma}$, and $\hat{m}$ along with the goodness-of-fit statistics RMS, AIC, BIC, MAD, and $R_{a}^{2}$ for the Logistic, Von Bertalanffy, Brody, Gompertz, Richards, and Proposed models adjusted to data on Santa Inês sheep.

\begin{tabular}{|c|c|c|c|c|c|c|c|c|c|c|}
\hline \multirow{2}{*}{ Models } & \multicolumn{5}{|c|}{ Parameters } & \multicolumn{5}{|c|}{ Indicators } \\
\hline & $\hat{\alpha}$ & $\hat{\beta}$ & $\hat{k}$ & $\hat{\gamma}$ & $\hat{m}$ & RMS & $\mathrm{AIC}$ & $\mathrm{BIC}$ & MAD & $R_{a}^{2}$ \\
\hline Logistic & 23.20 & 4.37 & 0.029 & & & 0.24 & 14.92 & 15.24 & 0.32 & 0.9973 \\
\hline Von Bertalanffy & 24.88 & 0.48 & 0.016 & & & 0.07 & 3.10 & 3.39 & 0.16 & 0.9991 \\
\hline Brody & 27.61 & 0.88 & 0.009 & & & 0.31 & 16.31 & 16.62 & 0.37 & 0.9965 \\
\hline Gompertz & 24.22 & 1.87 & 0.019 & & & 0.04 & 1.27 & 1.60 & 0.15 & 0.9991 \\
\hline Richards & 24.40 & 0.20 & 0.018 & & 9.54 & 0.05 & 2.80 & 3.20 & 0.14 & 0.9991 \\
\hline Proposed & 23.30 & -2.33 & 0.008 & -1.01 & & 0.03 & -0.19 & 0.21 & 0.09 & 1.0000 \\
\hline
\end{tabular}

The estimated growth rate $\hat{k}$ showed great variability among the models, between 0.008 and 0.029 . Since the maturity rate indicates the growth rate until asymptotic weight is reached, the values of $\hat{k}$ may be interpreted as indicators of precocity. High $\hat{k}$ values indicate precocious maturity compared with animals with low $\hat{k}$ of similar initial weight (MALHADO et al., 2009).

The Gompertz model stood out over its competition in a study on Santa Inês sheep from birth to 196 days of age (SARMENTO et al., 2006b). In that study, the estimated values of the parameters were as follows: Logistic $(\hat{\alpha}=23.17, \hat{\beta}=4.37$, and $\hat{k}=0.029)$, Von Bertalanffy $(\hat{\alpha}=24.81, \hat{\beta}$ $=0.48$; and $\hat{k}=0.016)$, Brody $(\hat{\alpha}=27.41, \hat{\beta}=$ 0.88 , and $\hat{k}=0.009)$, Gompertz $(\hat{\alpha}=24.17 ; \hat{\beta}$ $=1.87$, and $\hat{k}=0.019)$, and Richards $(\hat{\alpha}=24.55$, $\hat{\beta}=0.34, \hat{k}=0.017$, and $\hat{m}=4.64)$. It is worth pointing out that, according to Table 3 , those results match the ones found in the present study.

In Teixeira Neto et al. (2016), the values of $34.75 \mathrm{~kg}$ (Logistic), $39.68 \mathrm{~kg}$ (Von Bertalanffy), 48.89 (Brody), and $37.56 \mathrm{~kg}$ (Gompertz) found for $\hat{\alpha}$, when describing the growth of Santa Inês sheep reared in a semi-intensive system, were higher than the respective models in the present study (see Table 3).
It is known that the full development of tissues and organs is a reflection of physiological maturity. According to Amaral et al. (2011), Santa Inês males are considered large animals and may reach from 120 to $150 \mathrm{~kg}$ at maturity. For Toral (2008), the $\hat{\alpha}$ estimate may be subject to errors since the data adjusted by growth functions occasionally do not comprehend the animal's growth until maturity.

However, the estimated asymptotic weight of a given breed may differ as a function of other factors. In such situation, the difference found among the studies may lie in animal management since the asymptotic weight may be impacted by breed and rearing system (MALHADO et al., 2008b).

According to $R_{a}^{2}$ values, the models assessed were virtually identical, with a slight superiority of the Proposed model. The RMS, AIC, BIC, and MAD statistics for the Proposed model were the lowest $(0.03 ;-0.19 ; 0.21$, and 0.09$)$, thus, it can be indicated to adjust the growth curves of Santa Inês sheep, hence it was the model that combined weight and maturity close to observed data with the best fit to the weights observed.

As previously mentioned, this was corroborated by the clustering analysis, which indicated the formation of four clusters (Figure 4), one with the Logistic and Brody models, another with the 
Von Bertalanffy and Richards models, a third one growth curve adjusted by the Proposed model for with the Gompertz model, and the fourth with the the data of Santa Inês sheep.

Proposed model. Figure 5 shows the patterns of the

Figure 4. Dendrogram obtained by the clustering method based on the RMS, AIC, BIC, MAD, and $R_{a}^{2}$ statistics for the Logistic, Von Bertalanffy, Brody, Gompertz, Richards, and Proposed models.

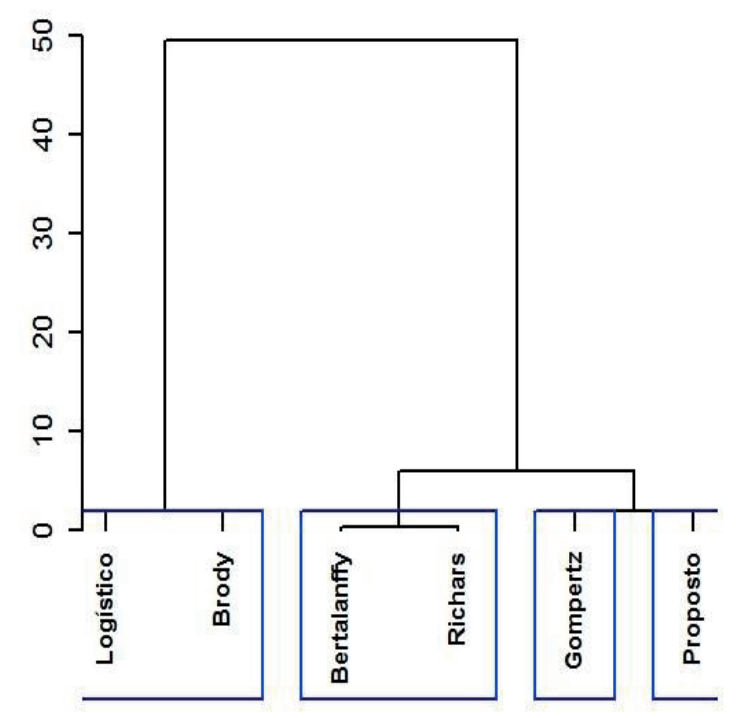

Figure 5. Weight as a function of age according to the Proposed model observed in Santa Inês goats.

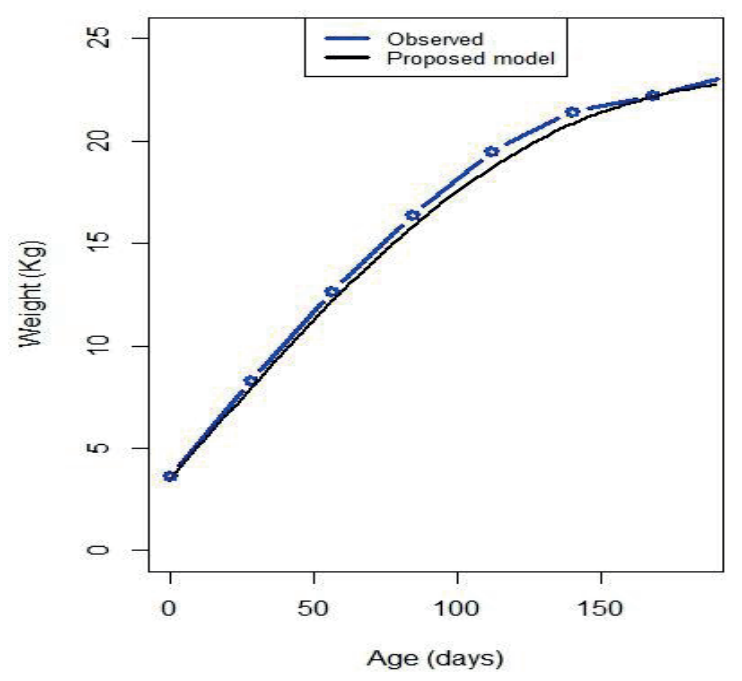

AGR rose until reaching the maximum of about $0.100 \mathrm{~kg} /$ day and then decreased with age. The curve's inflection point was reached at 125 days with weight of $8.6 \mathrm{~kg}$ (Figure 6). Results in previous studies on Santa Inês sheep reared at EMEPA in the state of Paraíba, Brazil, found AGR rising up to $0.170 \mathrm{~kg} /$ day and the inflection point at 52 days of age with weight of $8.9 \mathrm{~kg}$ (SARMENTO et al., 2006b). However, for studies on sheep of the same breed reared in the Brazilian state of Piauí, the AGR was $0.28 \mathrm{~kg}$ /day and the inflection point was reached at 28 days of age with weight of $6.40 \mathrm{~kg}$ (DO Ó et al., 2012). 
Figure 6. AGR estimated by the Proposed model based on sheep data.

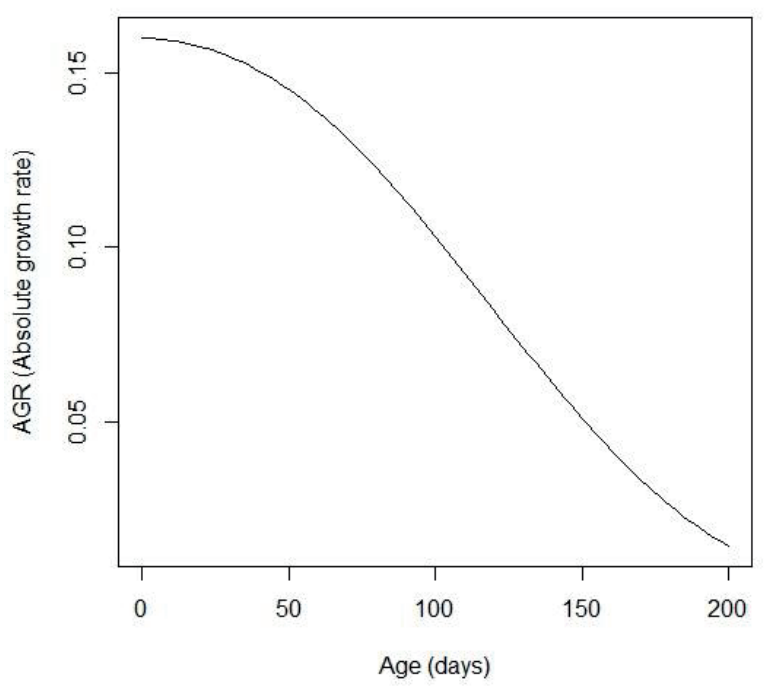

The growth rate begins to slow down at the inflection point due to several factors that gradually hinder growth, although the animal does not stop growing. Sarmento et al. (2006b) highlighted that the decrease in AGR may be the result of improper management to follow the greater demand for nutrients as the animal grows.

The estimated correlation between parameters $\alpha$ and $k$ was significant and negative (-0.79), matching the findings by Sarmento et al. (2006b) and Oliveira et al. (2009), which indicates that precocious animals are less likely to reach heavy weights at maturity. It must be pointed out that this is the most biologically important relation.

\section{Conclusion}

Based on the biological interpretations of the parameters and the goodness-of-fit measures, we can conclude the Proposed model was superior to the others. Therefore, the non-linear Proposed model in this research proved the most appropriate to describe growth curves of UB goats and Santa Inês sheep according to the methodology and conditions under which the present study was carried out.

\section{References}

AKAIKE, H. A new look at the statistical model identication. IEEE Transactions on Automatic Control, Boston, v. 19, n. 16, p. 716-723, dec. 1974.

AMARAL, R. M.; MACEDO, F. A. F.; MACEDO, F. G.; LINO, D. A.; ALCALDE, C. R.; DIAS, F. B.; GUALDA, T. P. Deposição tecidual em cordeiros Santa Inês, $1 / 2$ Dorper-Santa Inês e $1 / 2$ White Dorper-Santa Inês avaliados por ultrassonografia. Revista Brasileira Saúde e Produção Animal, Salvador, v. 12, n. 3, p. 658-669, 2011.

BRITO, C. C. R.; SILVA, J. A. A.; FERREIRA, R. L. C.; SANTOS, E. S.; FERRAZ, I. Modelos de crescimento resultantes da combinação e variações dos modelos de Chapman-Richards e Silva-Bailey aplicados em Leucaena leucocephala (Lam.) de Wit. Ciência Florestal, Santa Maria, v. 17, n. 2, p. 175-185, 2007.

BRODY, S. Bioenergetics and growth. New York: Reinhold Publication Corporation, 1945. 1023 p.

BROWN, J. E.; FITZHUGH JUNIOR, H. A.; CARTWRIGHT, T. C. A. A comparison of nonlinear models for describing weight-age relationships in cattle. Journal of Animal Science, Champaign, v. 42, n. 4, p. 810-818, 1976.

CARNEIRO, P. L. S.; MALHADO, C. H. M.; AFONSO, P. R. A. M.; PERREIRA, D. G.; SUART, J. C. C.; RIBEIRO JÚNIOR, M.; ROCHA, J. L. Curva de crescimento em caprinos, da raça Mambrina, criados na caatinga. Revista Brasileira Saúde e Produção Animal, Salvador, v. 10, n. 3, p. 536-545, 2009. 
CARNEIRO, P. L. S.; MALHADO, C. H. M.; SOUZA JÚNIOR, A. A. O.; SILVA, A. G. S.; SANTOS, P. F.; PAIVA, S. R. Desenvolvimento ponderal e diversidade fenotípica entre cruzamentos de ovinos Dorper com raças locais. Pesquisa Agropecuária Brasileira, Brasília, v. 42, n. 7, p. 991-998, 2007.

CAVALCANTE, D. H.; CAMPELO, J. E. G.; SOUSA JÚNIOR, S. C.; SOUSA, G. G. T.; ARAÚJO, J. I. M.; ARAUJO, A. C.; FONSECA, W. J. L.; BARROS JUNIOR, C. P.; ARAÚJO, A. M. Modelos não paramétricos para ajustes de curva de crescimento em caprinos Sem Raça Definida (SRD). Ciências Agrárias Ambiental, Curitiba, v. 11, n. 3, p. 283-289, 2013.

CHALH, A.; EL GAZZAH, M. Variogram investigation of covariance shape within longitudinal data with possible use of a krigeage technique as an interpolation tool: Sheep growth data as an example. Irish Journal of Agricultural and Food Research, Killarney, v. 53, n. 1, p. 51-64, 2014.

DA SILVA, J. A. A. Dynamics of stand structure in fertilized slash pine plantations. 1986. Thesis (Doctor of Philosophy) - University of Georgia, Athens.

DO Ó, A. O.; RÊGO NETO, A.A.; SANTOS, G.V.; SARMENTO, J.L.R; BIAGIOTTI, D.; SOUSA, J.E.R. Curva de crescimento de ovinos Santa Inês no Vale do Gurgueia. Revista Brasileira Saúde e Produção Animal, Salvador, v. 13, n. 4, p. 912-922, 2012.

GUEDES, M. H. P.; MUNIZ, J. A.; SILVA, F. F.; AQUINO, L. H. Análise Bayesiana da curva de crescimento de cordeiros da raça Santa Inês. Arquivo Brasileiro de Medicina Veterinária e Zootecnia, Belo Horizonte, v. 57, n. 3, p. 415-417, 2005.

HUBERT, L. J.; ARABIE, P. Comparing partitions. Journal of Classification, New York, v. 2, n. 1, p. 193218, 1985.

IBM SPSS Statistics 1.0. Software. New York: IBM Corporation, [2017?]. Disponível em: <https://www. ibm.com/br-pt/marketplace/spss-statistics $>$. Acesso em: 12 set. 2017.

LAIRD, A. K. Dynamcs of relative growth. Growth, Lakeland, v.29, n. 9, p. 249-263, 1965.

LIMA FILHO, L. M. F. Modelos simétricos não lineares de produção e crescimento em volume de clones de Eucalyptus spp. 2012. Tese (Doutorado em Biometria e Estatística Aplicada) - Departamento de Estatística e Informática, Universidade Federal Rural de Pernambuco, Recife.

MALHADO, C. H. M.; CARNEIRO, P. L. S.; CRU, J. F. da; OLIVEIRA, D. F. de; AZEVEDO, D. M. M. R.; SARMENTO, J. L. R. Curvas de crescimento para caprinos da raça Anglo-Nubiana criados na caatinga: rebanho de elite e comercial. Revista Brasileira de Saúde e Produção Animal, Salvador, v. 9, n. 4, p. 662-671, 2008a.

MALHADO, C. H. M.; CARNEIRO, P. L. S.; MELLO, P. R. A. M.; SOUZA JÚNIOR, A. A. O.; SARMENTO, J. L. R. Growth curves in Dorper sheep crossed with the local Brazilian breeds, Morada Nova, Rabo Largo, and Santa Inês. Small Ruminant Research, Amsterdam, v. 84, n. 1-3, p. 16-21, 2009.

MALHADO, C. H. M.; CARNEIRO, P. L. S.; SANTOS, P. F.; AZEVEDO, D. M. M.; SOUZA, J. C.; AFFONSO, P. R. M. Curva de crescimento em ovinos mestiços Santa Inês x Texel criados no Sudoeste do Estado da Bahia. Revista Brasileira Saúde e Produção Animal, Salvador, v. 9, n. 2, p. 210-218, 2008 b.

McMANUS, C.; EVANGELISTA, C.; FERNANDES, L. A. C.; MIRANDA, R. M.; MORENO-BERNAL, F. E.; SANTOS, N. R. Curvas de crescimento de ovinos Bergamácia criados no Distrito Federal. Revista Brasileira de Zootecnia, Viçosa, MG, v. 32, n. 5, p. 1207 1212, 2003.

McMANUS, C. M.; LOUVANDINI, H.; CAMPOS, V. A. L. Non linear growth curves for weight and height in four genetic groups of horses. Ciência Animal Brasileira, Goiânia, v. 11, n. 1, p. 80-89, 2010.

NELDER, J. A. The fitting of a generalization of the logistic curve. Biometrics, Washington, v. 17, n. 1, p. 89110, 1961.

OLIVEIRA, D. F.; CRUZ, J. F.; CARNEIRO, P. L. S.; MALHADO, C. H. M.; RONDINA, D.; FERRAZ, R. C. N.; TEIXEIRA NETO, M. R. Desenvolvimento ponderal e características de crescimento de caprinos da raça Anglo-Nubiana criados em sistema semi-intensivo. Revista Brasileira de Saúde e Produção Animal, Salvador, v. 10, n. 2, p. 256-265, 2009.

PIRES, L. C.; MACHADO, T. M. M.; CARNEIRO, P. L. S.; SILVA, J. B. L.; BARBOSA, A. D. H.; TORRES, R. A. Curva de crescimento de caprinos Repartida criados na Caatinga. Semina: Ciências Agrárias, Londrina, v. 38, n. 2, p. 1041-1050, 2017.

PRODUÇÃO PECUÁRIA MUNICIPAL, Rio de Janeiro: IBGE, v. 40, p. 1-71, 2012.

RICHARDS, F. J. A flexible growth function for empirical use. Journal of Experimental Botany, Lancaster, v. 10, n. 2, p. 290-300, 1959.

SANTANA, A. F.; COSTA, G. B.; FONSECA, L. S. Correlações entre peso e medidas corporais em ovinos jovens da raça Santa Inês. Revista Brasileira Saúde Produção Animal, Salvador, v. 1, n. 5, p. 74-77, 2001. 
SANTANA, T. J. S.; SCALON, J. D.; BITTENCOUT, T. C. C.; SANTANA, A. S. A. Modelo Von Bertalanffy com resposta em platô para descrever curvas de crescimento de bovinos de corte. Revista Brasileira de Biometria, Lavras, v. 34, n. 4, p. 646-655, 2016.

SARMENTO, J. L. R.; REGAZZI, A. J.; SOUSA, W. H.; TORRES, R. A.; BREDA, F. C.; MENEZES, G. R. O. Estudo de curvas de crescimento de ovinos Santa Inês. Revista Brasileira de Zootecnia, Viçosa, MG, v. 35, n. 2, p. 435-444, 2006b.

SARMENTO, J. L. R.; TORRES, R. A.; PEREIRA, C. S.; SOUSA, W. H.; LOPES, P. S.; ARAÚJO, C. V.; EUCLYDES, R. F. Avaliação genética de características de crescimento de ovinos Santa Inês utilizando modelos de regressão aleatória. Arquivo Brasileiro Medicina Veterinária e Zootecnia, Belo Horizonte, v. 58, n. 1, p. 68-77, 2006a.

SCHWARZ, G. Estimating the dimensional of a model. Annals of Statistics, Hayward, v. 6, n. 2, p. 461-464, mar. 1978.

SOUSA, J. E. R.; SILVA, M. A.; SARMENTO, J. L. R.; SOUSA, W. H.; SOUZA, M. S. M. Avaliação da trajetória média de crescimento de caprinos em modelos de regressão aleatória. Archivos de Zootecnia, Córdoba, v. 59, n. 226, p. 267-276, 2010.

SOUSA, J. E. R. de; SARMENTO, J. L. R.; SOUZA, W. H. de; SOUZA, M. do S. M. de; SOUSA JÚNIOR, S. C. de; DO, Ó, A. O.; SANTOS, G. V. dos. Aspectos genéticos da curva de crescimento de caprinos AngloNubiano. Revista Brasileira de Saúde e Produção Animal, Salvador, v. 12, n. 2, p. 340-349, 2011.
SOUZA, L. A.; CARNEIRO, P. L. S.; MALHADO, C. H. M.; PAIVA, S. R.; CAIRES, D. N.; BARRETO, D. L. F. Curvas de crescimento em ovinos da raça Morada Nova criados no estado da Bahia. Revista Brasileira de Zootecnia, Viçosa, MG, v. 40, n. 8, p. 1700-1705, 2011.

SOUZA, L. D. A.; CARNEIRO, P. L. S.; MALHADO, C. H. M.; SILVA, F. F.; SILVEIRA, F. G. D. Traditional and alternative nonlinear models for estimating the growth of Morada Nova sheep. Revista Brasileira de Zootecnia, Viçosa, MG, v. 42, n. 9, p. 651-655, 2013.

TEIXEIRA NETO, M. R.; CRUZ, J. F da; FARIA, H. H. N.; SOUZA, E. S.; CARNEIRO, P. L. S; MALHADO, C. H. M. Descrição do crescimento de ovinos Santa Inês utilizando modelos não-lineares selecionados por análise multivariada. Revista Brasileira de Saúde e Produção Animal, Salvador, v. 17, n. 1, p. 26-36, 2016.

TEIXEIRA, M. C.; VILLARROEL, A. B.; PEREIRA, E. S.; OLIVEIRA, S. M. P.; ALBUQUERQUE, I. A.; MIZUBUTI, I. Y. Curva de crescimento de cordeiros oriundos de três sistemas de produção na Região Nordeste do Brasil. Semina: Ciências Agrárias, Londrina, v. 33, n. 5, p. 2011-2018, 2012.

TORAL, F. L. B. Número e intervalo de pesagens para estimação de parâmetros de curvas de crescimento em bovinos. Revista Brasileira de Zootecnia, Viçosa, MG, v. 37, n. 12, p. 2120-2128, 2008.

VON BERTALANFFY, L. Quantitative laws for metabolism and growth. The Quarterly Review of Biology, New York, v. 32, n. 3, p. 217-231, 1957. 
